\title{
Mid-latitude ozone changes: studies with a 3-D CTM forced by ERA-40 analyses
}

\author{
W. Feng ${ }^{1}$, M. P. Chipperfield ${ }^{1}$, M. Dorf ${ }^{2}$, K. Pfeilsticker ${ }^{2}$, and P. Ricaud ${ }^{3}$ \\ ${ }^{1}$ Institute for Atmospheric Science, School of Earth and Environment, University of Leeds, Leeds, UK \\ ${ }^{2}$ Institute für Umweltphysik, University of Heidelberg, Heidelberg, Germany \\ ${ }^{3}$ Laboratoire d'Aerologie, Observatoire Midi-Pyrenees, Toulouse, France
}

Received: 3 April 2006 - Published in Atmos. Chem. Phys. Discuss.: 17 July 2006

Revised: 16 April 2007 - Accepted: 23 April 2007 - Published: 9 May 2007

\begin{abstract}
We have used an off-line three-dimensional (3-D) chemical transport model (CTM) to study long-term changes in stratospheric $\mathrm{O}_{3}$. The model was run from 1977-2004 and forced by ECMWF ERA-40 and operational analyses. Model runs were performed to examine the impact of increasing halogens and additional stratospheric bromine from short-lived source gases. The analyses capture much of the observed interannual variability in column ozone, but there are also unrealistic features. In particular the ERA-40 analyses cause a large positive anomaly in northern hemisphere $(\mathrm{NH})$ column $\mathrm{O}_{3}$ in the late 1980s. Also, the change from ERA-40 to operational winds at the start of 2002 introduces abrupt changes in some model fields (e.g. temperature, ozone) which affect analysis of trends. The model reproduces the observed column increase in $\mathrm{NH}$ mid-latitudes from the mid 1990s. Analysis of a run with fixed halogens shows that this increase is not due to a significant decrease in halogen-induced loss, i.e. is not an indication of recovery. The model predicts only a small decrease in halogen-induced loss after 1999. In the upper stratosphere, despite the modelled turnover of chlorine around 1999, $\mathrm{O}_{3}$ does not increase because of the effects of increasing ECMWF temperatures, decreasing modelled $\mathrm{CH}_{4}$ at this altitude, and abrupt changes in the SH temperatures at the end of the ERA-40 period. The impact of an additional $5 \mathrm{pptv}$ stratospheric bromine from short-lived species decreases mid-latitude column $\mathrm{O}_{3}$ by about $10 \mathrm{DU}$. However, the impact on the modelled relative $\mathrm{O}_{3}$ anomaly is generally small except during periods of large volcanic loading.
\end{abstract}

Correspondence to: M. P. Chipperfield

(martyn@env.leeds.ac.uk)

\section{Introduction}

A quantitative explanation of the observed changes in midlatitude column ozone has still not been achieved. Although the likely contributing processes have been identified (e.g. see WMO, 2003) their relative importance is still not clear. These processes include chemical loss due to increased halogens and dynamical changes. Halogen-induced loss partly depends on aerosol loading which provides a link with volcanic eruptions. Variations in solar output (e.g. the 11-yr solar cycle) also affect ozone at mid-lower latitudes. One issue is that all of the different processes have not yet been brought together in a single long-term model study. In addition, temporal changes in the observed variations mean that the separation of "trend" from long-term "variability" depends on the period considered, i.e. the relative importance of processes to the apparent trend will change as the length of time series changes.

In a series of papers Hadjinicolaou and co-workers have studied the influence of dynamics on northern hemisphere (NH) column ozone using an off-line 3-D transport model (SLIMCAT) forced by ECMWF analyses. Hadjinicolaou et al. (2002) ran the model from 1979-1998 using analyses with a top lid at $10 \mathrm{hPa}$ and showed that the model captured many observed variations in NH column ozone. Recently, Hadjinicolaou et al. (2005) have performed a similar CTM study from 1957-2003 using analyses which extend to $0.1 \mathrm{hPa}$ (ERA-40 until 2001 and then operational). This study again showed that the model captured alot of the observed NH column ozone variability and, interestingly, the model reproduced the observed increase in $\mathrm{NH}$ column ozone after the mid 1990s.

Chipperfield (2003) used a similar model set-up to Hadjinicolaou et al. (2002) but with detailed stratospheric chemistry to perform long-term simulations. He cautioned that the modelled dynamical variability in the 1990s, when the model

Published by Copernicus Publications on behalf of the European Geosciences Union. 
Table 1. CTM experiments.

\begin{tabular}{lll}
\hline Run & Halogens & $\mathrm{Br}_{\mathrm{y}}$ sources \\
\hline $\mathbf{A}$ & time-dependent & $\mathrm{CH}_{3} \mathrm{Br}+$ Halons + VSLS + trop. $\mathrm{Br}_{\mathrm{y}}$ \\
$\mathbf{B}$ & fixed & $\mathrm{CH}_{3} \mathrm{Br}+$ Halons + VSLS + trop. $\mathrm{Br}_{\mathrm{y}}$ \\
$\mathbf{C}$ & time-dependent & $\mathrm{CH}_{3} \mathrm{Br}$ only \\
D & time-dependent & $\mathrm{CH}_{3} \mathrm{Br}$ only but total bromine scaled to match $\mathbf{A}$ \\
\hline
\end{tabular}

a 1979 tropospheric values.

was forced by operational analyses, did not match the observations well. Nevertheless, by running the model with timedependent and fixed halogen loadings he argued that halogen changes did dominate the observed trends from 1980 until the early 1990s. However, the vertical extent of the ERA15 analyses, and their short time period, limited this study. Recently, Stolarski et al. (2006) used a full chemistry CTM, forced by winds from a general circulation model, to investigate ozone trends. They found that their model, which included observed changes in halogens and aerosol, was able to reproduce much of the long term globally average variations in column ozone over the past 20 years.

Recently, the bromine loading of the stratosphere has received a lot of attention. Many past studies (e.g. Sinnhuber et al., 2002) have used BrO observations to infer that the inorganic bromine $\left(\mathrm{Br}_{\mathrm{y}}\right)$ loading of the stratosphere is currently around 21 pptv. Salawitch et al. (2005) discussed the stratosphere bromine budget and showed that this inferred $\mathrm{Br}_{\mathrm{y}}$ loading is greater than that delivered by long-lived organic source gases by between 4-8 pptv. This discrepancy can be accounted for by contributions from short-lived bromine source gases. The study by Salawitch et al. (2005) included 2-D (latitude-height) model calculations of the impact of this extra 4-8 pptv on NH mid-latitude column $\mathrm{O}_{3}$. This additional $\mathrm{Br}_{\mathrm{y}}$ increased the modelled $\mathrm{O}_{3}$ loss, notably around the time of the large aerosol loading from Mt. Pinatubo in the early 1990s. However, 2-D models cannot be expected to capture the interaction of polar loss with mid-latitudes realistically.

Past model studies have sometimes based their bromine loading solely on the long-lived species (e.g. WMO, 2003) in which cases the model will fall short of the observed loading by around $6 \mathrm{pptv}$, and the model will underestimate the impact of bromine chemistry on $\mathrm{O}_{3}$. Other studies (e.g. Chipperfield, 1999) have assumed a more realistic loading of $\sim 20$ pptv by increasing the model abundance of a long-lived source gas to account for the short-lived species not explicitly included in the model. This approach is reasonable for most of the stratosphere but discrepancies in $\mathrm{Br}_{\mathrm{y}}$ might be expected in young air in the lower stratosphere.

In this paper we have used the SLIMCAT 3-D offline chemical transport model (CTM) with a detailed stratospheric chemistry scheme to perform full-stratosphere decadal integrations. We examine the role of chemical processes on mid-latitude ozone changes and the effect of bromine from short-lived substances. This paper is therefore an update of Chipperfield (2003) with longer-term, full stratosphere simulations using ERA-40 analyses. It revisits some issues raised in the northern hemisphere (NH) study of Hadjinicolaou et al. (2005) using a model with a full chemistry scheme. Finally, we add to the bromine study of Salawitch et al. (2005) by using a full 3-D model. Section 2 describes the model and experiments. Section 3 discusses the model results and Section 4 summarises our conclusions.

\section{Model and experiments}

\subsection{SLIMCAT 3-D CTM}

SLIMCAT is an off-line 3-D CTM described in detail by Chipperfield (1999). The model has been used in many past studies of stratospheric chemistry and shown to perform reasonably at simulating key chemistry and transport processes. The model uses a hybrid $\sigma-\theta$ vertical coordinate (Chipperfield, 2006) and extends from the surface to a top level which depends on the domain of the forcing analyses. Vertical advection in the $\theta$-level domain (above $350 \mathrm{~K}$ ) is calculated from diabatic heating rates using a radiation scheme which gives a better representation of vertical transport and ageof-air even with ERA-40 analyses than using vertical winds derived from the analyses which have known problems (e.g. van Noije et al., 2004; Chipperfield, 2006). The model contains a detailed stratospheric chemistry scheme including a treatment of heterogeneous reactions on liquid aerosols, nitric acid trihydrate (NAT) and ice (see Chipperfield, 1999). The current details of the chemistry scheme are as described in Feng et al. (2005). The modelled $\mathrm{O}_{3}$ field is used in the calculation of diabatic heating rates.

For the runs described here two extra tracers for bromine source gases have been added to the model. These represent a halon and a very short-lived species (VSLS) and were set up using the photochemical data for $\mathrm{H} 1211$ and $\mathrm{CH}_{2} \mathrm{Br}_{2}$ respectively. In the model experiments the surface mixing ratios of these tracers are set to the total values of all halon species and a constant $4 \mathrm{pptv}$ respectively. In addition, the tropospheric $\mathrm{Br}_{\mathrm{y}}$ mixing ratio was set at $1 \mathrm{pptv}$.

In the experiments described here the 3-D model resolution was $7.5^{\circ} \times 7.5^{\circ}$ with 24 levels from the surface to approximately $60 \mathrm{~km}$. The model was forced using the 6-hourly 60-level European Centre for Medium-Range Weather Forecasts (ECMWF) analyses. From 1 January 1977 to 31 December 2001 we have used the standard "ERA-40" product (Uppala et al., 2005). After this date we have used the operational analyses which are subject to periodic update. Timedependent monthly fields of liquid sulfate aerosol for 19791999 were taken from WMO (2003). When the model simulations extended beyond 1999 the aerosol was kept constant 
at the 1999 values. The time-dependent surface mixing ratios of source gases were also taken from WMO (2003).

The model was initialised on 1 January 1977 using output from a 2-D model and integrated until 2004 in a series of experiments (see Table 1). Run A used the basic model and time-dependent values for the halogen loading and aerosols. Run B was similar to A but used a tropospheric halogen loading fixed at 1979 values. Run $\mathbf{C}$ was similar to $\mathbf{A}$ but did not include the contribution of bromine from the VSLS tracer nor the direct input of $\mathrm{Br}_{\mathrm{y}}$ from the troposphere, i.e. the total bromine loading was 5 pptv less than run A. Finally, run $\mathbf{D}$ was similar to $\mathbf{A}$ except that all of the model tropospheric bromine was put into the form of $\mathrm{CH}_{3} \mathrm{Br}$ to mimic the approach used in older SLIMCAT studies (e.g. Chipperfield, 1999, 2003).

\section{Results}

\subsection{Bromine loading}

Figure 1 shows an example of observed $\mathrm{BrO}$ profiles from Kiruna $\left(67^{\circ} \mathrm{N}\right)$ on 24 March 2004 using the University of Heidelberg balloon-borne DOAS instrument (e.g. Dorf et al., 2006). DOAS BrO measurements indicate that at present the inorganic bromine $\left(\mathrm{Br}_{\mathrm{y}}\right)$ loading in the stratosphere is around 21 pptv and therefore 4-5 pptv larger than the known organic precursors, halons and $\mathrm{CH}_{3} \mathrm{Br}$ (around $16.5 \mathrm{pptv}$ in 5 year old air, see Montzka et al., 2003), can account for. Detailed model comparisons (Dorf, 2005) reveal that the major part of this discrepancy can be explained by short-lived organic bromine species (VSLS) and their injection into the stratosphere. Direct injection of tropospheric inorganic bromine into the stratosphere possibly also contributes to a lesser extent (around $1 \mathrm{pptv}$ ). The fast release of $\mathrm{Br}_{\mathrm{y}}$ and the rapid increase of $\mathrm{BrO}$ above the tropopause can particularly be observed for the tropical measurements at Teresina (see Dorf et al., $2007^{1}$ ) but the difference is also present at high latitudes.

Also shown in Fig. 1 are profiles of bromine species from the basic model run (A) and the run which mimics our former treatment of all tropospheric bromine released as $\mathrm{CH}_{3} \mathrm{Br}$ (D). Although the overall bromine loading is set to be the same (around $21 \mathrm{pptv}$ during this period) run $\mathbf{A}$ has a larger mixing ratio of $\mathrm{Br}$ below $\sim 25 \mathrm{~km}$ through non-zero tropospheric $\mathrm{Br}$ and faster overall release of bromine from its source gases. This leads to around 1-2 pptv more $\mathrm{BrO}$ between $15-25 \mathrm{~km}$ which gives better agreement with these balloon flights. A discussion of other flights, which confirm the improved agreement of run $\mathbf{A}$ is given in Dorf et

\footnotetext{
${ }^{1}$ Dorf, M., Bösch, H., Butz, A., Camy-Peret, C., Chipperfield, M. P., Grunow, K., Harder, H., Kritten, L., Payan, S., Simmes, B., Weidner, F., and Pfeilsticker, K.: Comparison of measured and modelled low, mid- and high latitude stratospheric BrO profiles: The need for very short-lived bromo-organic species (VSLS), in preparation, 2007.
}

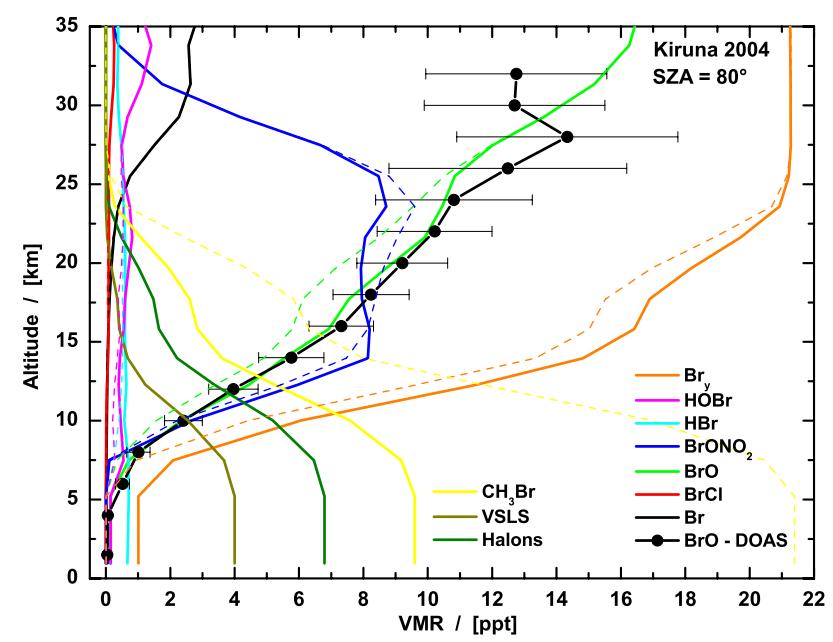

Fig. 1. DOAS-observed profile of $\mathrm{BrO}$ volume mixing ratio (pptv, circles) at Kiruna $\left(67^{\circ} \mathrm{N}\right)$ on 24 March 2004. Also shown are model profiles of $\mathrm{Br}_{\mathrm{y}}$ species and bromine source gases from runs $\mathbf{A}$ (solid lines) and $\mathbf{D}$ (dashed lines).

al. $(2007)^{1}$. Clearly, the model run $\mathbf{C}$, which does not consider the 5 pptv contribution from VSL species, will significantly underestimate the observed $\mathrm{BrO}$ (not shown).

\subsection{Polar ozone}

Figure 2 compares the modelled column $\mathrm{O}_{3}$ for the $\mathrm{SH}$ (October) and NH (March) polar regions (area weighted between $63^{\circ}-90^{\circ}$ ) from runs $\mathbf{A}$ and $\mathbf{B}$ along with satellite observations. This diagnostic is now commonly used to show longterm changes in polar springtime ozone (e.g. Newman et al., 1997 and later references). Comparisons with previous SLIMCAT model runs have been shown in Chipperfield and Jones (1999) and Chipperfield (2003), and results from this later paper are included for comparison. As already stated in these previous studies, the $\mathrm{O}_{3}$ field from the basic model (run A) captures much of the interannual variability in the column ozone. Compared to Chipperfield (2003), the newer ERA-40 model runs perform much better in capturing the variability from 1992-1997 which was completely missed by the older 31-level ECMWF analyses in the northern hemisphere. In fact, the newer model runs perform well through 2003 in both hemispheres and reproduce the variability in the recent years.

Comparison of the passive and chemically integrated tracers and the model runs $\mathbf{A}$ and $\mathbf{B}$ allow us to diagnose the magnitude of chemical polar loss and the contribution from recent increases in halogens. Note that the curves for run $\mathbf{A}$ and $\mathbf{B}$ only clearly start to diverge after 1985 . This is due to the time lag for tropospheric air to reach the high latitude lower stratosphere; i.e. run B had fixed (1979) tropospheric halogens which correspond to the polar stratospheric loading of around 5 years later. Therefore, the difference between run $\mathbf{A}$ and run $\mathbf{B}$ only diagnoses the contribution of halogen 


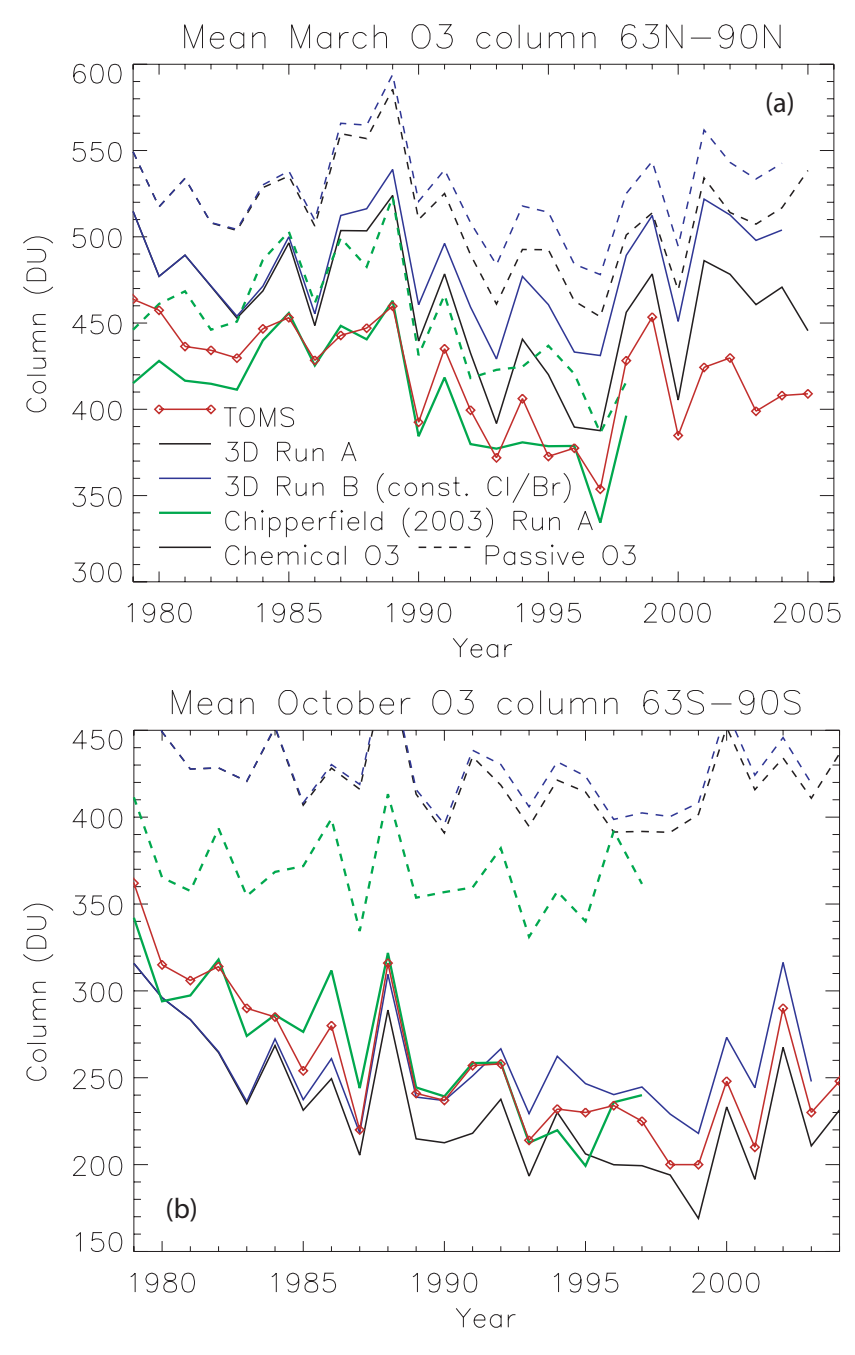

Fig. 2. Mean TOMS column $\mathrm{O}_{3}$ poleward of (a) $63^{\circ} \mathrm{N}$ in March and (b) $63^{\circ} \mathrm{S}$ in October (updated from Newman et al. (1997) to show later years). Also shown are the corresponding model (chemically integrated and passive ozone) results from runs $\mathbf{A}$ and $\mathbf{B}$. (The passive $\mathrm{O}_{3}$ tracer is reset equal to the chemically integrated $\mathrm{O}_{3}$ every 1 July and 1 January then advected in the model without any further chemical change. The difference between the passive $\mathrm{O}_{3}$ and the corresponding chemically integrated $\mathrm{O}_{3}$ indicates the chemical $\mathrm{O}_{3}$ loss since this time). Also included are results from run $\mathrm{A}$ of Chipperfield (2003) until March 1998. Note different ranges on y-axes.

increases after this time. Compared to Chipperfield (2003) the modelled $\mathrm{O}_{3}$ columns are larger for all runs in the northern hemisphere. This is due to various factors. First, the new model runs extend down to the surface rather than having a lower boundary at $350 \mathrm{~K}$ which is overwritten with climatological values. Hence, the model $\mathrm{O}_{3}$ column is now sensitive to the predicted values in the lowermost stratosphere which are overestimated. Second, the new model runs use ERA-40 winds which, despite using the most realistic formulation of
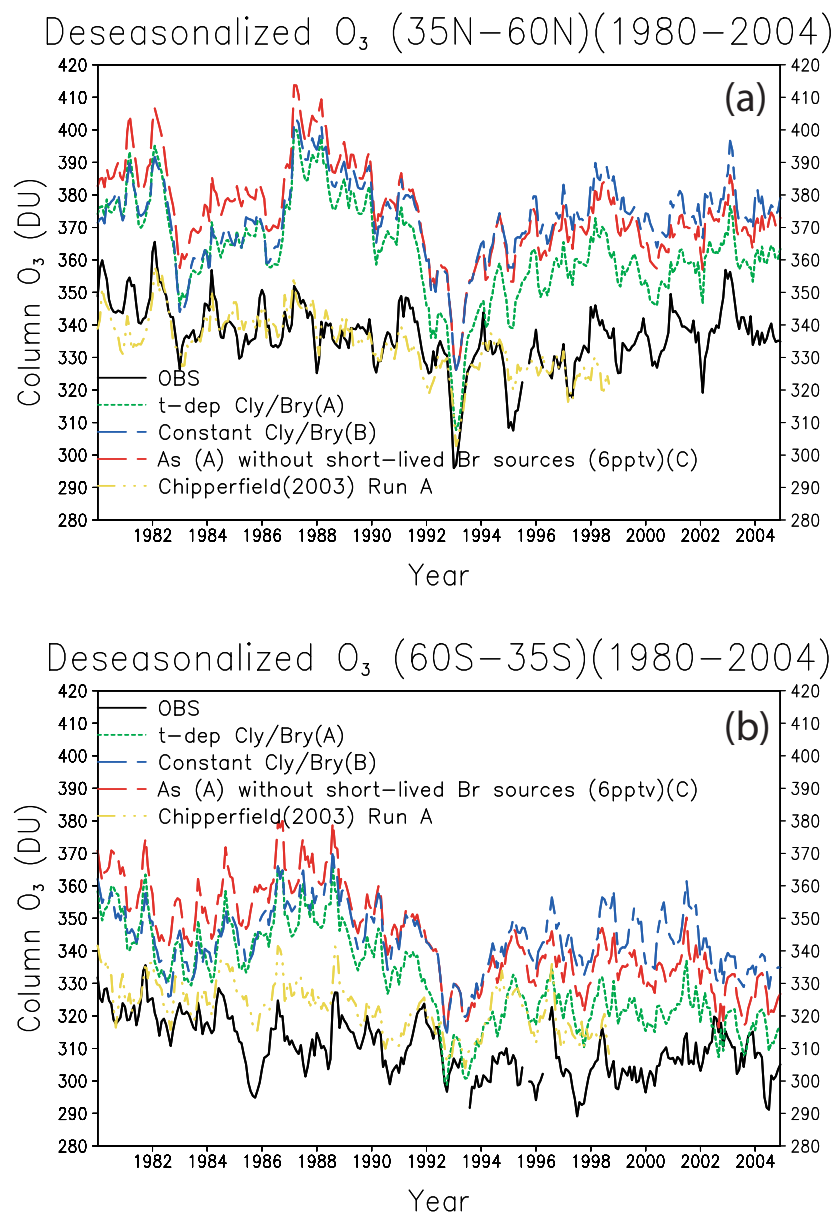

Fig. 3. Deseasonalised column $\mathrm{O}_{3}$ weight-averaged within latitude bands (a) $35^{\circ} \mathrm{N}-60^{\circ} \mathrm{N}$ and (b) $35^{\circ} \mathrm{S}-60^{\circ} \mathrm{S}$ from TOMS/SBUV observations (black line). Also shown are the deasonalised columns from model runs A, B and C and Run A from Chipperfield (2003) until 1998.

the model (i.e. heating rates and $\sigma-\theta$ levels), might tend to give too strong a circulation. Another significant difference with respect to Chipperfield (2003) is the diagnosis of the overall chemical loss (from 1 July) in the SH. This is now much greater (i.e. $170 \mathrm{DU}$ in 1985 in run $\mathbf{A}$ versus $100 \mathrm{DU}$ in the equivalent run in Chipperfield (2003)). This is due to both a change in the modelled transport (which affects the passive tracers) and an increase in the modelled chemical loss (see Chipperfield et al., 2005). In the southern hemisphere the increased chemical ozone loss masks the increase in model $\mathrm{O}_{3}$ due to transport/lower boundary other effects.

\subsection{Mid-latitude column ozone}

Figure 3 shows a comparison of zonal mean column $\mathrm{O}_{3}$ in the $\mathrm{NH}$ and $\mathrm{SH}$ mid latitudes from satellite observations and the model runs. The observations are the merged TOMS/SBUV dataset of R. Stolarski (personal communication, 2005). This 

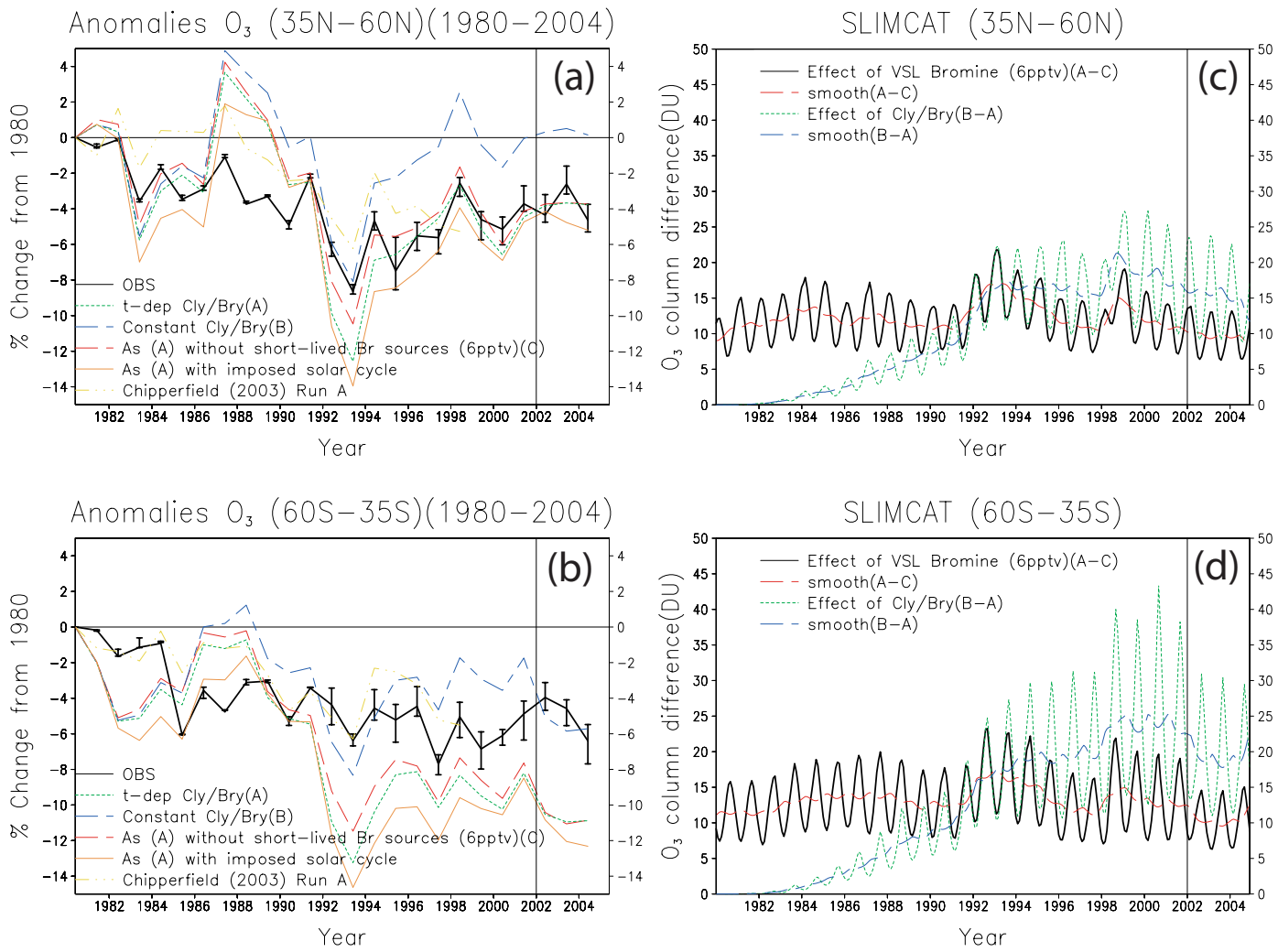

Fig. 4. Change in satellite-observed zonal mean, annual mean column ozone compared to 1980 weight-averaged within latitude bands (a) $35^{\circ} \mathrm{N}-60^{\circ} \mathrm{N}$, and (b) $35^{\circ} \mathrm{S}-60^{\circ} \mathrm{S}$. Also shown are model results from model runs $\mathbf{A}, \mathbf{B}$ and $\mathbf{C a n d} \mathbf{A}$ with an imposed solar cycle (see text). The model output was saved every 2 days. Also shown are results from Chipperfield (2003) run A (until 1998). Panels (c) and (d) show the difference in column $\mathrm{O}_{3}$ (DU) between runs B-A, and runs $\mathbf{C}$-A for the same two regions along with the equivalent lines with a 12-month smoothing. The vertical line in all panels around 2002 marks the change in the forcing winds from ERA-40 to operational analyses.

dataset uses Nimbus 7 TOMS and SBUV, the NOAA 9, 11, and 14 SBUV/2 and the Earth Probe TOMS. Generally the model columns overestimate the observations. This difference is largest in the late 1980s when the model values in the $\mathrm{NH}$ are up to $70 \mathrm{DU}$ too large. Compared with previous full chemistry SLIMCAT runs (e.g. Chipperfield, 1999) this worse agreement is due to the extension of the model lower boundary from around $350 \mathrm{~K}$ down to the surface. The model now predicts $\mathrm{O}_{3}$ in the lowermost stratosphere, rather than it being prescribed, and with the ERA40 analyses this is overestimated, similar to the polar regions (see Sect. 3.2).

Figures $4 \mathrm{a}$ and $\mathrm{b}$ compare the observed anomaly of the annual mean column ozone (expressed as \% change since 1980) for the $\mathrm{NH}\left(35^{\circ} \mathrm{N}-60^{\circ} \mathrm{N}\right)$ and the $\mathrm{SH}\left(35^{\circ} \mathrm{S}-60^{\circ} \mathrm{S}\right)$. Overall, model run $\mathbf{A}$ reproduces the observed decrease in column ozone in these regions between 1980 and the mid 1990s, although it overestimates the decrease in the SH. As seen in previous CTM runs (e.g. Chipperfield, 2003) the model does capture some of the long-term variability although there are significant differences. The model has a strong positive deviation in the late 1980s and too strong a dip in the early 1990s. These are likely more accentuated in our run than that of Hadjinicolaou et al. (2005) because we include the full depth of the stratosphere. In addition some of the observed variability on the timescale of a few years is reproduced by the model, especially before the early 1990s in the NH. Later in the 1990s the modelled variations do not agree as well and this again is likely related at least in part to the changing ECMWF analyses. It should be noted that after the change of the model forcing winds from ERA-40 to operational winds (31 December 2001) there is a noticeable change in the modelled anomaly in the SH.

As noted in Chipperfield (2003) the CTM used here does not contain a parameterisation of the effects of the 11-yr solar cycle. However, to examine the possible impacts of the solar cycle on mid-latitude ozone the same procedure as described in Chipperfield (2003) has been followed. A solar cycle variation of $2 \%$ (solar maximum - solar minimum, in phase with the F10.7 flux) has been imposed on the results of $\mathbf{A}$, assuming the model solar fluxes represent solar maximum conditions. This imposed solar cycle causes a negative deviation in the modelled anomaly away from solar maximum periods. This decreases the model overestimate in the late 1980s but makes the model negative anomaly around 1992/93 deeper 

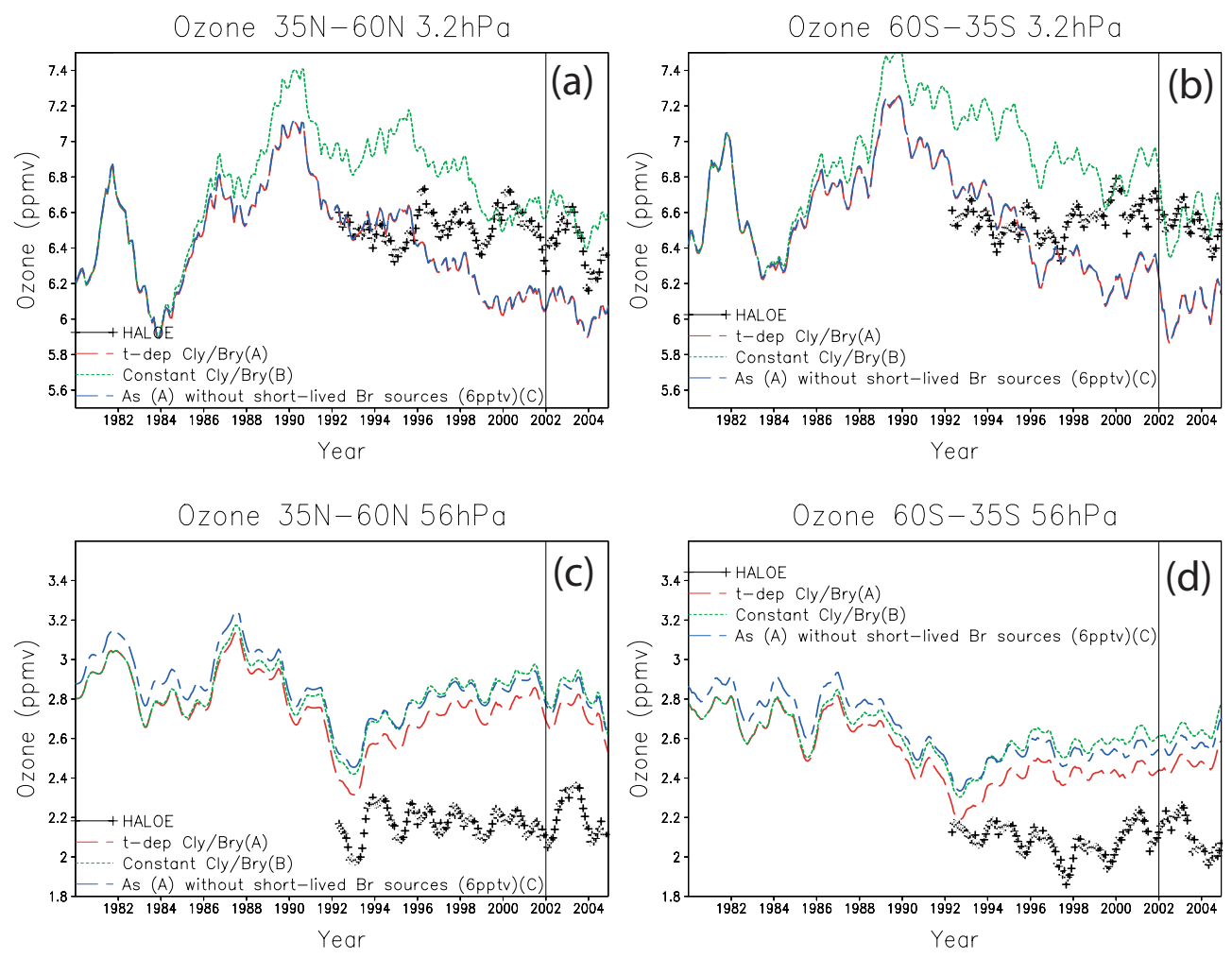

Fig. 5. Variation of $\mathrm{O}_{3}$ mixing ratio (ppmv) from 1980-2004 for model runs $\mathbf{A}$ (black), B (red dashed) and $\mathbf{C}$ (green dotted line) for (a) $35^{\circ} \mathrm{N}-60^{\circ} \mathrm{N}$ at $3.2 \mathrm{hPa}(\sim 40 \mathrm{~km})$, (b) $35^{\circ} \mathrm{S}-60^{\circ} \mathrm{S}$ at $3.2 \mathrm{hPa}$, (c) $35^{\circ} \mathrm{N}-60^{\circ} \mathrm{N}$ at $56 \mathrm{hPa}(\sim 20 \mathrm{~km})$, and (d) $35^{\circ} \mathrm{S}-60^{\circ} \mathrm{S}$ at $56 \mathrm{hPa}$. The model lines have been smoothed with a 12-month running mean. At $40 \mathrm{~km}$ the results for runs Aand $\mathbf{C}$ are very similar. Also shown are monthly mean observations from HALOE (+) from 1992 onwards.

than observations. In contrast to the ERA15 runs of Chipperfield (2003), including the effects of the solar cycle does not clearly improve the model comparison over the whole time period considered.

Including the additional constant 5 pptv of $\mathrm{Br}_{\mathrm{y}}$ from shortlived species tends to decrease mid-latitude column $\mathrm{O}_{3}$ by around $10 \mathrm{DU}$ throughout the model runs (Figs. 4c, d). When the $\mathrm{O}_{3}$ anomaly is calculated with respect to the appropriate 1980 levels, the anomaly from run $\mathbf{C}$ is very similar to run B except during periods of high aerosol loading where an enhanced decrease (of around 2\%) is seen.

\subsection{Lower and upper stratosphere}

Figure 5 shows the variation in $\mathrm{O}_{3}$ mixing ratio at $\mathrm{NH}$ and SH mid-latitudes at $56 \mathrm{hPa}(\sim 20 \mathrm{~km})$ and $3.2 \mathrm{hPa}(\sim 40 \mathrm{~km})$ for three model runs and HALOE observations. In the upper stratosphere there is some variability but model $\mathrm{O}_{3}$ declines from the late 1980s through 2004 in disagreement with the observations. The decline is larger in the runs with increasing halogens but run $\mathbf{B}$ still shows a similar variation. Clearly no particular model simulation is able to reproduce the observed trend. At $20 \mathrm{~km}$ the model overestimates $\mathrm{O}_{3}$, by up to $0.5 \mathrm{ppmv}$, which contributes to the column overestimation.
In the lower stratosphere the $\mathrm{O}_{3}$ variation reflects what happens to the total column with minimum values around 1993 followed by some increase. Note, however, that in the SH the column decrease after the change of forcing analyses in 2002 , is not seen in the $20 \mathrm{~km} \mathrm{O}_{3}$ but does coincide with an abrupt decrease at $40 \mathrm{~km}$. Figure 6 shows the equivalent results for the modelled total inorganic chlorine $\left(\mathrm{Cl}_{\mathrm{y}}\right)$. This shows the expected increase through the late 1990s followed by a peak and the recent turnover. In the model this seems to have occurred in $1998-2000$ at $40 \mathrm{~km}$ (run A); in the lower stratosphere the dynamical variability makes the situation less clear, though the maximum modelled values occurred around 2001. Given this change in $\mathrm{Cl}_{\mathrm{y}}$, which we expect to be a main driver for the model chemical $\mathrm{O}_{3}$ trend, it is useful to explore the factors that have contributed to the modelled $\mathrm{O}_{3}$ variations in the upper and lower stratosphere.

In the upper stratosphere, which is chemically more simple, the model $\mathrm{O}_{3}$ continues to decline through 2004, in disagreement with HALOE, despite the turnover in model $\mathrm{Cl}_{\mathrm{y}}$. Figures 7, 8, 9 and 10 show the corresponding plots of $\mathrm{CH}_{4}, \mathrm{H}_{2} \mathrm{O}, \mathrm{ClO}$ and temperature. Over this time period the changes in stratospheric $\mathrm{CH}_{4}$ are first driven by the increase in tropospheric $\mathrm{CH}_{4}$. In addition there is interannual variability in atmospheric transport which causes variability in $\mathrm{CH}_{4}$, 
Cly $35 \mathrm{~N}-60 \mathrm{~N} 3.2 \mathrm{hPa}$

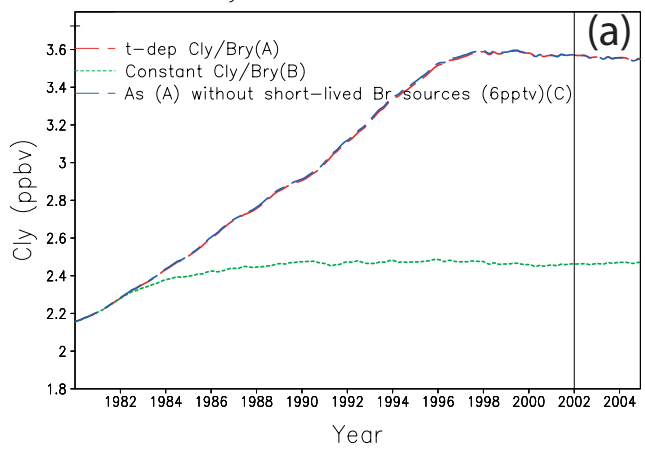

Cly $35 \mathrm{~N}-60 \mathrm{~N} 56 \mathrm{hPa}$

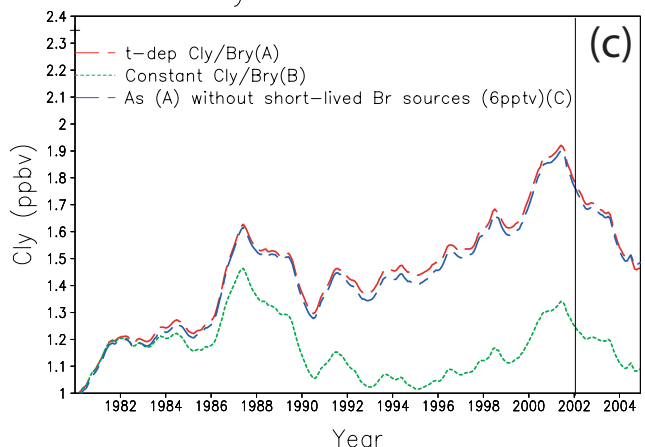

Cly $60 \mathrm{~S}-35 \mathrm{~S} 3.2 \mathrm{hPa}$

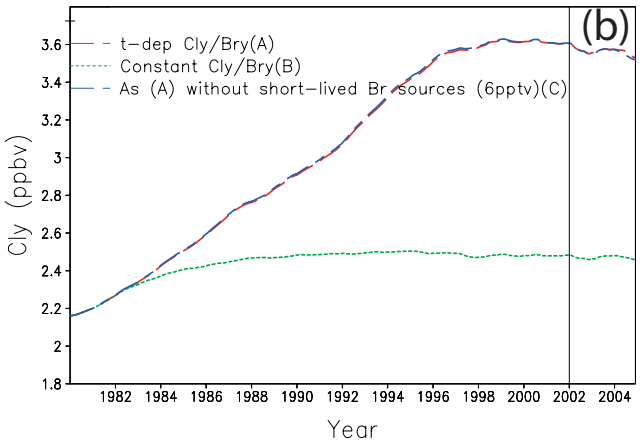

Cly $60 \mathrm{~S}-35 \mathrm{~S} 56 \mathrm{hPa}$

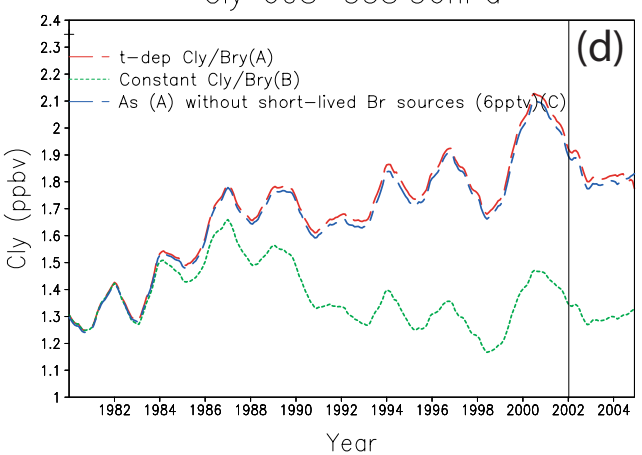

Fig. 6. As Figure 5 but for total inorganic chlorine $\left(\mathrm{Cl}_{\mathrm{y}}\right)(\mathrm{ppbv})$. There is no $\mathrm{HALOE}$ data for $\mathrm{Cl}_{\mathrm{y}}$.
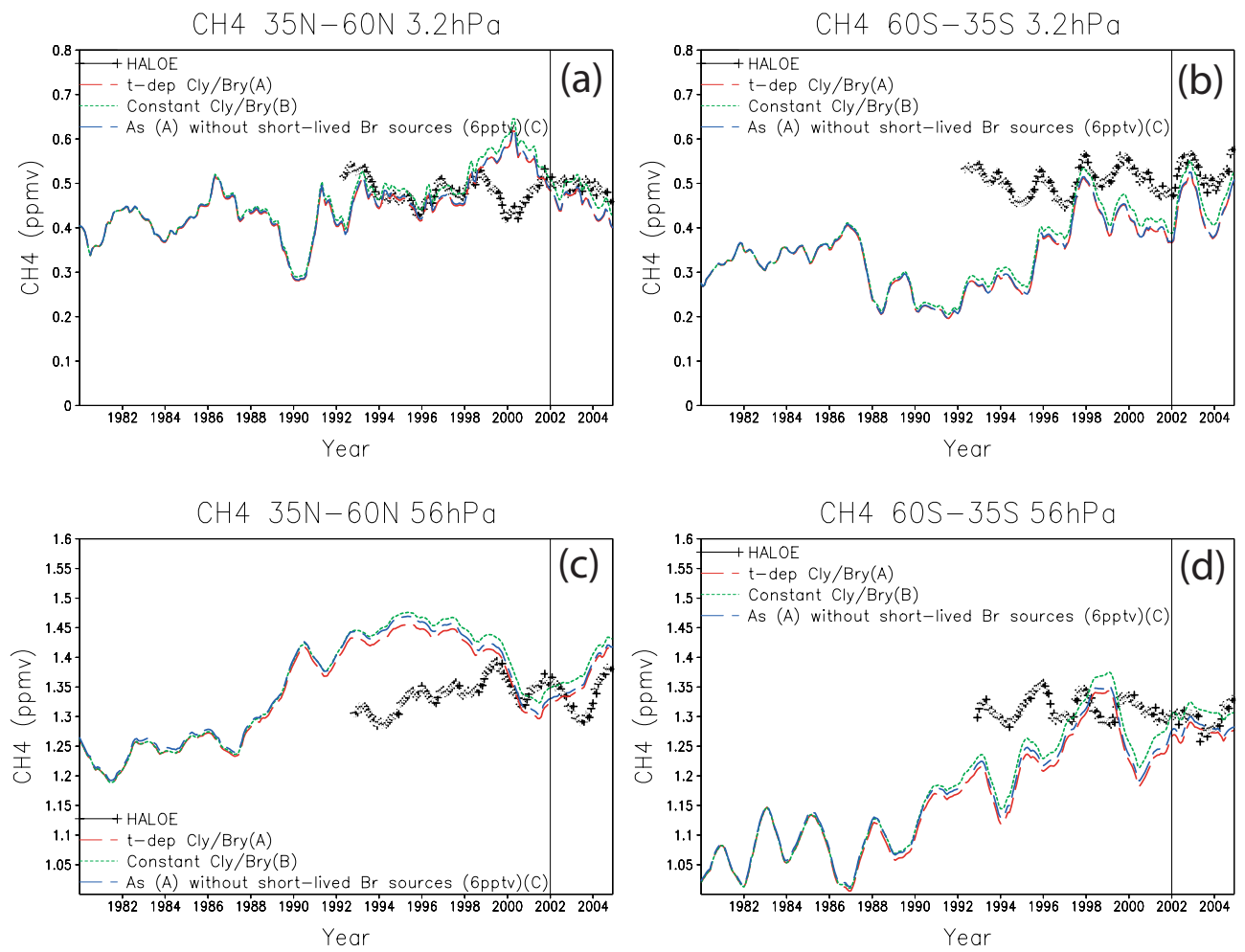

Fig. 7. As Fig. 5 but for $\mathrm{CH}_{4}$ (ppmv). At $56 \mathrm{hPa}$ HALOE data is plotted from 1993 onwards. 

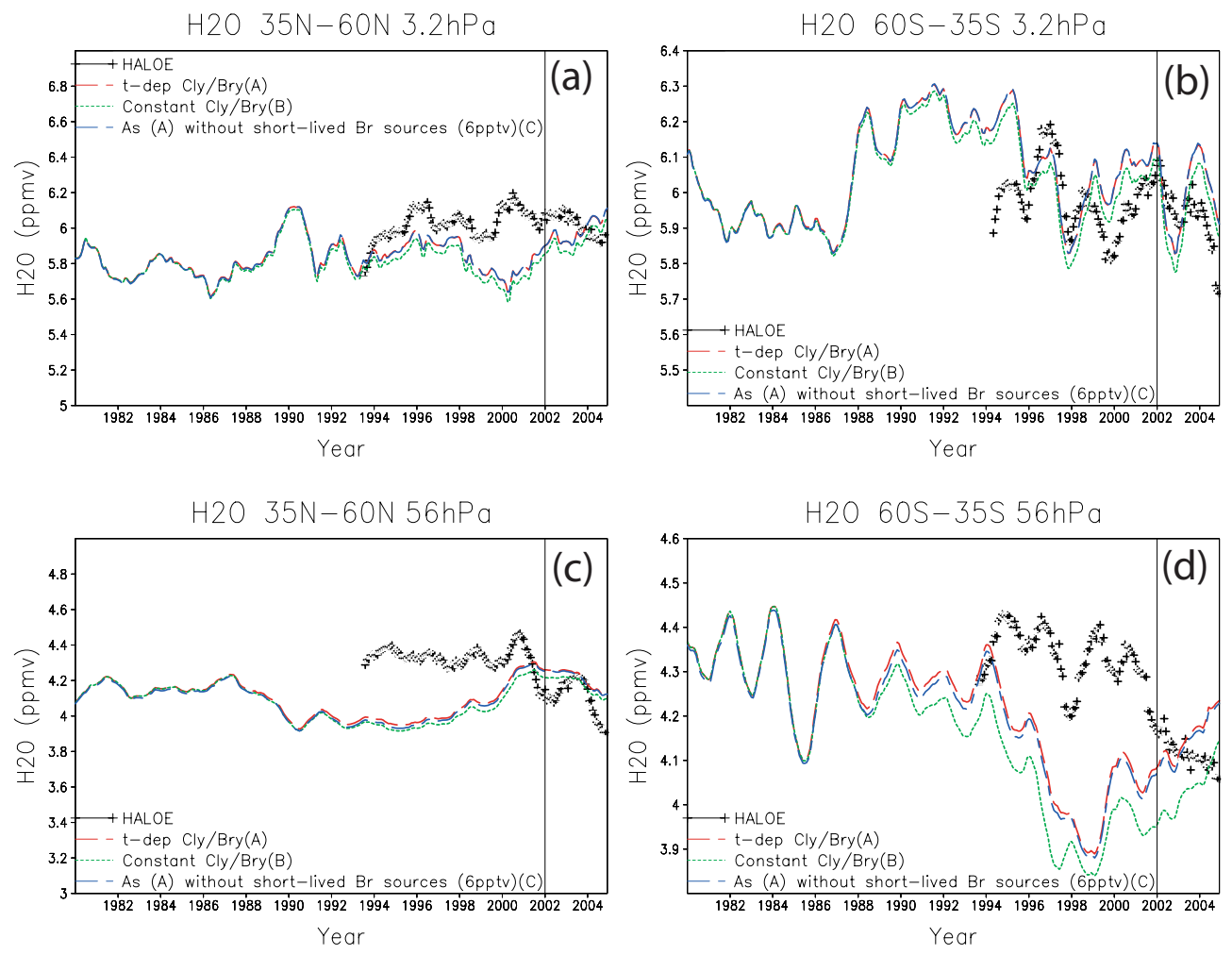

Fig. 8. As Fig. 5 but for $\mathrm{H}_{2} \mathrm{O}$ (ppmv). HALOE data is plotted from 1994 onwards.
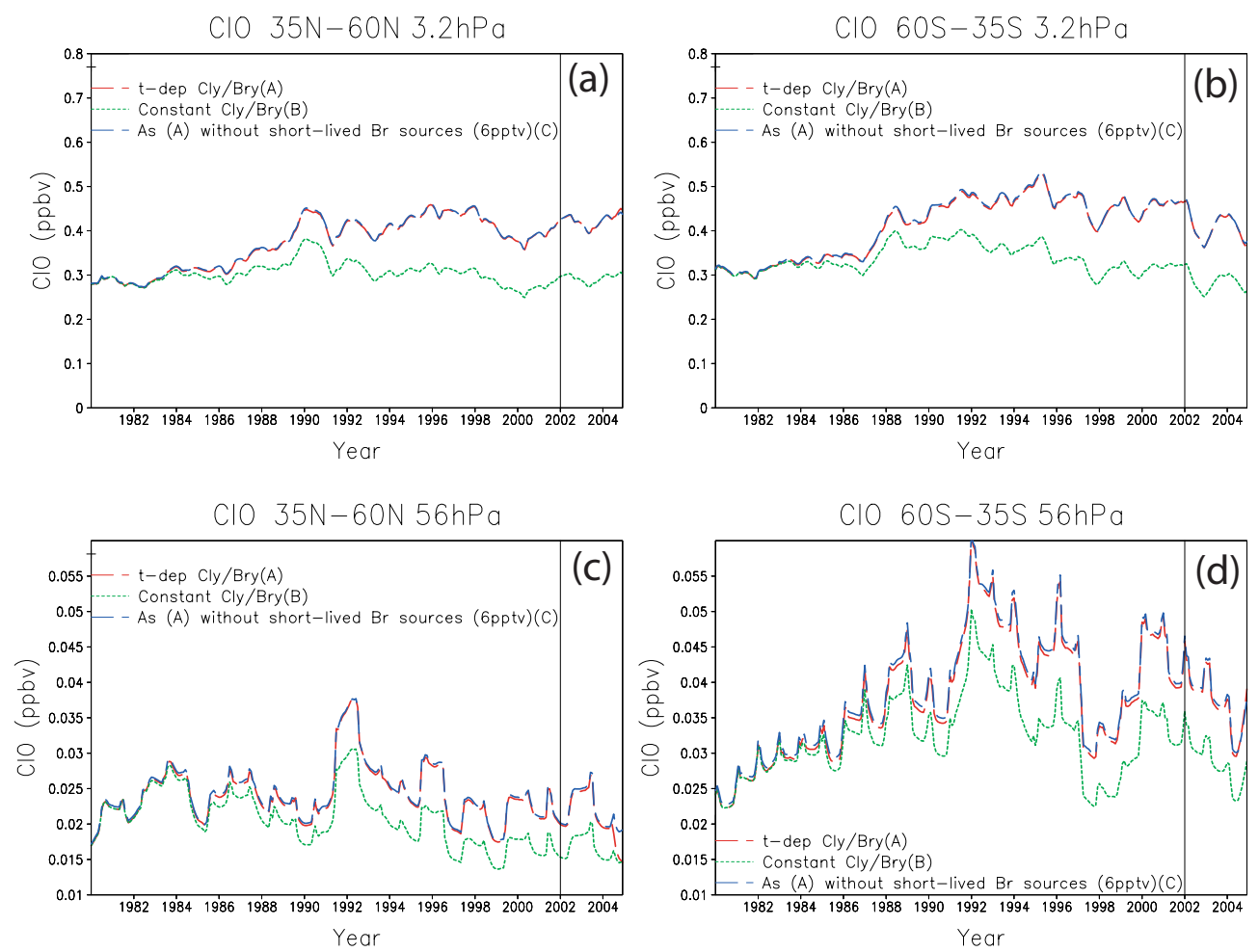

Fig. 9. As Fig. 5 but for $\mathrm{ClO}$ (ppbv). There is no HALOE data for $\mathrm{ClO}$. 

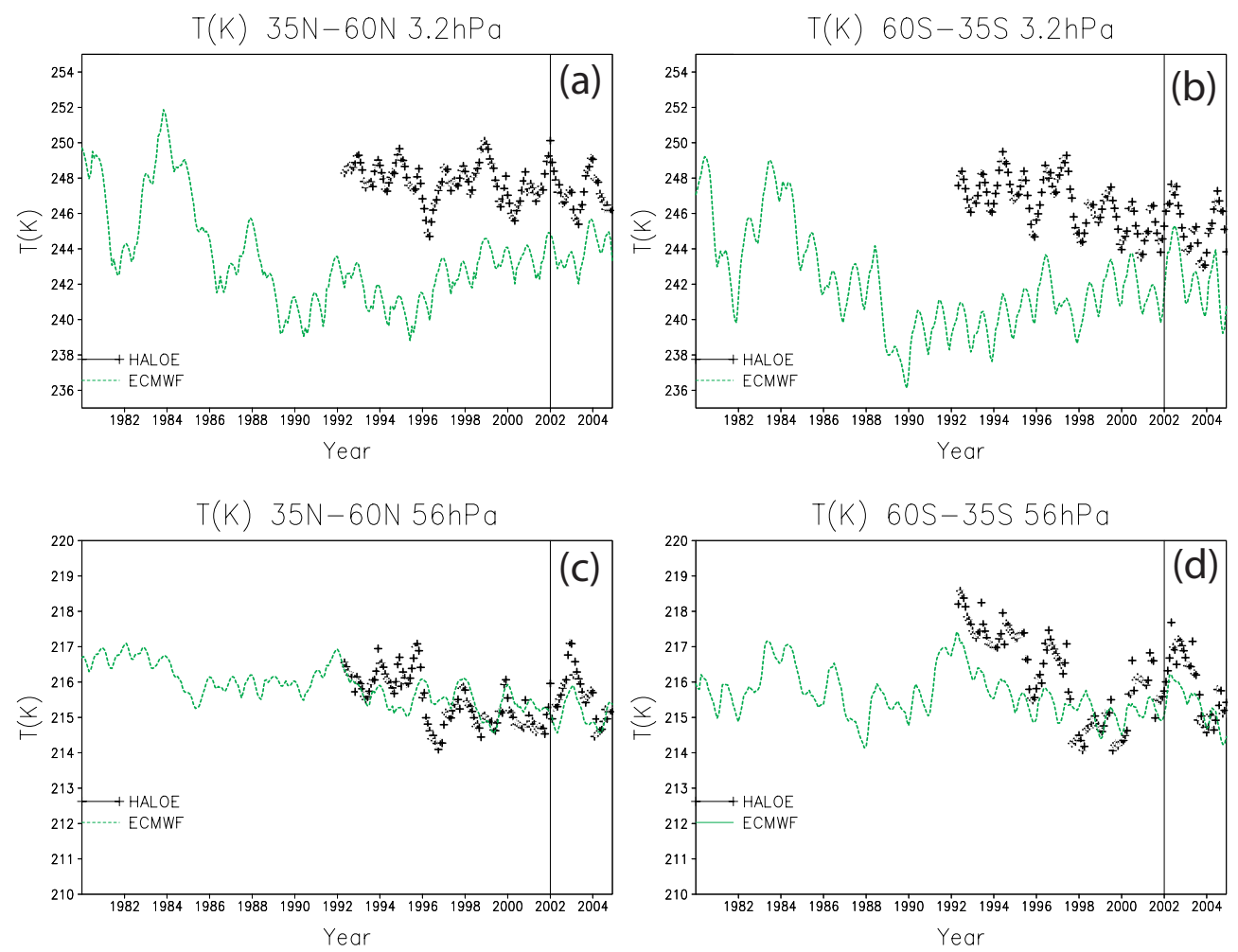

Fig. 10. Variation of temperature (K) from ECMWF for 1980-2004 (green line) and HALOE for 1992-2004 (+ symbols) for (a) $35^{\circ}$ N$60^{\circ} \mathrm{N}$ at $3.2 \mathrm{hPa}(\sim 40 \mathrm{~km})$, (b) $35^{\circ} \mathrm{S}-60^{\circ} \mathrm{S}$ at $3.2 \mathrm{hPa}$, (c) $35^{\circ} \mathrm{N}-60^{\circ} \mathrm{N}$ at $56 \mathrm{hPa}(\sim 20 \mathrm{~km})$ and (d) $35^{\circ} \mathrm{S}-60^{\circ} \mathrm{S}$ at $56 \mathrm{hPa}$. The lines have been smoothed with a 12-month running mean. The line at 1/1/2002 indicates the change from ERA-40 reanalyses to operational analyses.

which is generally anticorrelated with $\mathrm{Cl}_{\mathrm{y}}$ due to the opposing gradients. Notably, between 1996 and 2001 at $20 \mathrm{~km}$ in the $\mathrm{NH} \mathrm{CH}_{4}$ decreased, indicating a large role for dynamics in the model here. In the upper stratosphere there is larger relative variability. Although the modelled $\mathrm{CH}_{4}$ agrees fairly well in magnitude with the HALOE observations at the 2 altitudes, indicating that the rate of model transport to the upper stratosphere is reasonable, there are significant differences in trends. In the $\mathrm{SH}$ at both altitudes the model $\mathrm{CH}_{4}$ increases strongly from 1991 to 1998 while in the NH lower stratosphere the model $\mathrm{CH}_{4}$ decreases from 1994 to 1998. These changes are not in agreement with HALOE and indicate spurious model dynamical trends due to the forcing winds. The model $\mathrm{H}_{2} \mathrm{O}$ (Fig. 8) generally shows opposite discrepancies with HALOE compared to $\mathrm{CH}_{4}$, as would be expected from these coupled species. However, there are periods in the $\mathrm{SH}$ lower stratosphere (Fig. 8d) where the model underestimates both species (e.g. 1996, 2000).

Figures $9 \mathrm{a}, \mathrm{b}$ show the variation of $\mathrm{ClO}$ at $40 \mathrm{~km}$. Changes in $\mathrm{CH}_{4}$ will affect the partitioning of the two main $\mathrm{Cl}_{\mathrm{y}}$ reservoirs $\mathrm{ClO}$ and $\mathrm{HCl}$; increases in $\mathrm{CH}_{4}$ will tend to decrease ClO. Therefore the modelled $\mathrm{CH}_{4}$ changes after 2000, when $\mathrm{Cl}_{\mathrm{y}}$ is decreasing, have tended to increase $\mathrm{NH} \mathrm{ClO}$ (i.e. oppose $\mathrm{Cl}_{\mathrm{y}}$ changes) and decrease $\mathrm{SH} \mathrm{ClO}$. This leads to an overall larger decrease in $\mathrm{ClO}$ in the $\mathrm{SH}$.
Finally, Fig. 10 shows the model (ECMWF) temperatures at $40 \mathrm{~km}$ and $20 \mathrm{~km}$ along with HALOE data. The analyses tend to underestimate HALOE data by about up to $6 \mathrm{~K}$ in the upper stratosphere but agree better in the lower stratosphere. In the upper stratosphere warmer temperatures tend to decrease $\mathrm{O}_{3}$ due to faster catalytic loss. In the early $1980 \mathrm{~s}$ the analyses show unrealistically large $T$ variations of around $10 \mathrm{~K}$ in 2 years. The large decrease of temperature from 1984 to 1986 in both hemispheres leads to the $\mathrm{O}_{3}$ increase seen in Figs. 5a, b. After 1986 the NH temperatures tend to increase while the SH temperatures remain fairly constant with an abrupt increase around 2002. Therefore, in the model, upper stratosphere $\mathrm{O}_{3}$ does not increase post 2000, despite decreasing $\mathrm{Cl}_{\mathrm{y}}$, due to (i) decreasing $\mathrm{CH}_{4}$ and increasing temperatures in the $\mathrm{NH}$ and (ii) abrupt changes in the model meteorological fields in early 2002 in the SH due to a change of forcing analyses. This again illustrates the problem of diagnosing long-term changes from a single CTM experiment. Clearly, direct diagnosis of $\mathrm{O}_{3}$ recovery from the effects of halogen changes can be achieved by taking the difference between appropriate chemical model experiments. 

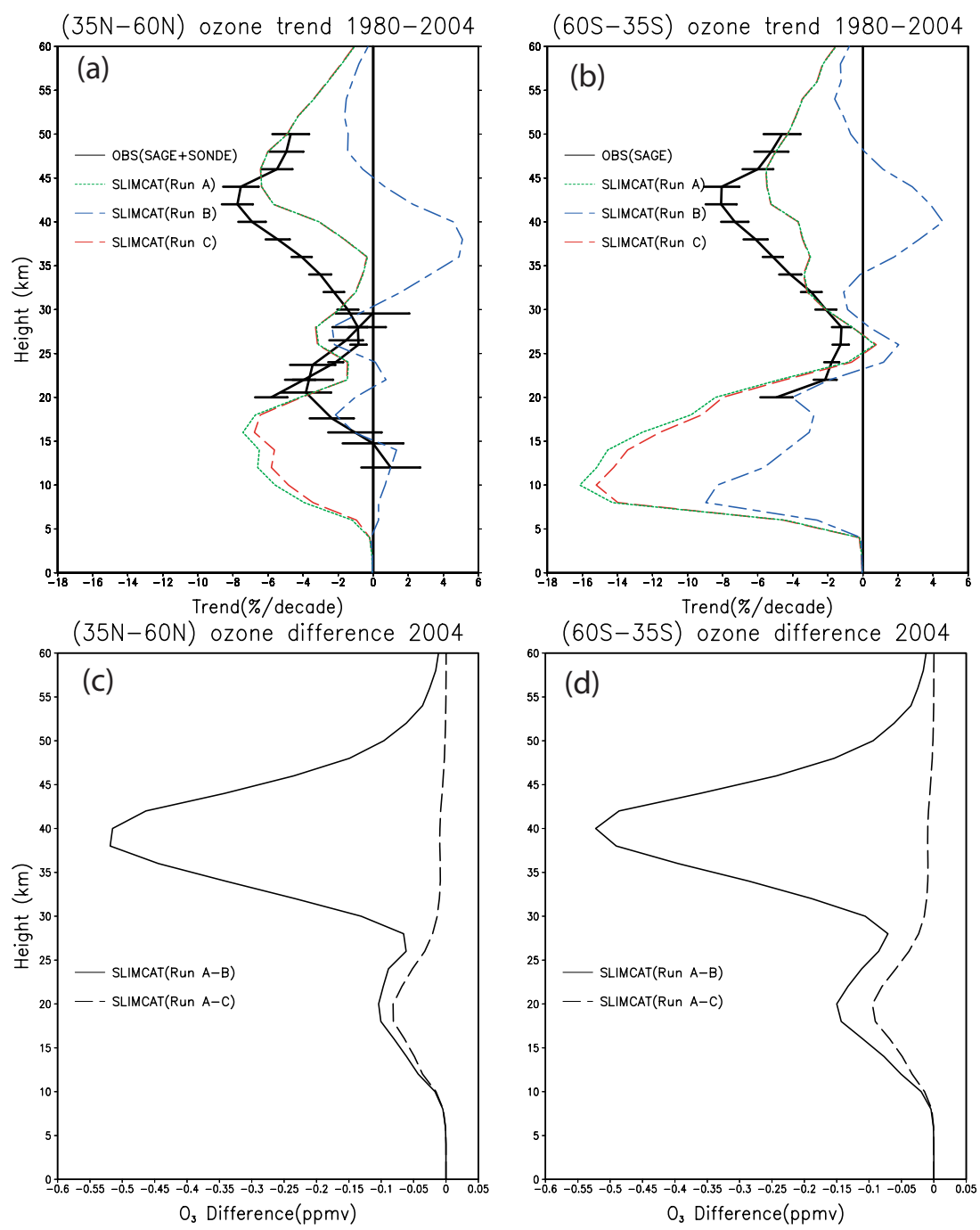

Fig. 11. Profile of modelled $\mathrm{O}_{3}$ trend (regressed onto an EESC curve) (\%/decade) from $1980-2004$ for runs $\mathbf{A}, \mathbf{B}$ and $\mathbf{C}$ for (a) $35^{\circ} \mathrm{N}-60^{\circ} \mathrm{N}$ and (b) $35^{\circ} \mathrm{S}-60^{\circ} \mathrm{S}$. Also show are profiles of $\mathrm{O}_{3}$ differences (ppmv) between runs $\mathbf{A}-\mathbf{B}$ and $\mathbf{A}-\mathbf{C}$ for the the year 2004 for $(\mathbf{c}) 35^{\circ} \mathrm{N}-60^{\circ} \mathrm{N}$ and (d) $35^{\circ} \mathrm{S}-60^{\circ} \mathrm{S}$.

\subsection{Mid-latitude profile changes}

An important step in the attribution of ozone changes to the correct cause is the matching of 'fingerprints' between observed and modelled changes (e.g. WMO, 2003). One such important test is to examine the profile of modelled ozone changes which contributes to the column mid-latitude changes described above. Figure 11 shows estimates of the modelled trend for 1980-2004 for runs A, B and C, along with differences between model runs for the year 2004 which shows the effect of increasing halogens (A-B) and additional bromine (A-C). The trends were diagnosed using a model (Ziemke et al., 1997) with a regression onto a term for the Effective Equivalent Stratospheric Chlorine (EESC, using an assumed bromine efficiency $(\alpha)$ of 60). The trend was converted from units of $\mathrm{O}_{3}$ loss per unit EESC to \%/decade by using the near-linear rate of change of EESC with time in the 1980s.

The observed trend, based on sonde data in the lower stratosphere and satellite data higher up, shows a characteristic double peak structure with maximum trends of around $-9 \% /$ decade near $40 \mathrm{~km}$ in both hemispheres and $-6 \% /$ decade in the $\mathrm{NH}$ lower stratosphere. (There is not enough sonde date in the SH for a trend analysis). The basic model run $\mathbf{A}$ tends to capture this structure although the $40 \mathrm{~km}$ peak is smaller and displaced upwards slightly while in the $\mathrm{NH}$ lower stratosphere the modelled trend is much larger than observed below $15 \mathrm{~km}$. The modelled lower stratosphere (LS) trend is larger in the SH $(-16 \% /$ decade), although there is no data for comparison. The trend from model run $\mathbf{B}$ differs from zero and also shows some of the vertical structure seen in the trend from run $\mathbf{A}$. In particular, 
it is interesting to note that run $\mathbf{B}$ has a positive trend near $40 \mathrm{~km}$ and a large negative trend in the $\mathrm{SH}$ lower stratosphere. Hence, this component of the modelled trend (i.e. dynamically induced or due to other chemistry) has acted to offset the halogen trend in the upper stratosphere (US) and increased the trend in the SH lower stratosphere. Figures 11c, d show the differences in $\mathrm{O}_{3}$ between runs $\mathbf{A}-\mathbf{B}$ and runs $\mathbf{A}-\mathbf{C}$. These profiles are much smoother and show the effect in 2004 of the overall halogen increases and increased stratospheric $\mathrm{Br}_{\mathrm{y}}$. The LS changes are now more symmetrical between the NH and SH. The $40 \mathrm{~km}$ change of -0.5 ppmv (Figs. 11c, d) corresponds to a change of around $-7 \% / d e c a d e$ for the 1985-2000 change in $\mathrm{Cl}_{\mathrm{y}}$. The lower stratospheric change of $-0.15 \mathrm{ppmv}$ corresponds to around -5 to $-7 \% /$ decade over the same period.

Clearly, taking the difference between 2 model runs with the same meteorology gives a much more direct and cleaner signal of the relevant chemical forcing. This is also seen in Fig. 12 which shows a latitude height plot of the percentage difference between runs $\mathbf{A}$ and $\mathbf{B}$. The increasing halogens (runs A-B) give the characteristic double peak structure with loss near $40 \mathrm{~km}$ due to the $\mathrm{ClO}+\mathrm{O}$ cycle as well as loss in the lower stratosphere near $20 \mathrm{~km}$. The "cleaner" diagnosis of ozone changes seen in Figs. 11c, d and 12 tend to be more similar to the trends derived from observations in terms of spatial variations (e.g. Fig. 4.9 of WMO, 2003). The equivalent plot of Fig. 12 diagnosed from the trend of run $\mathbf{A}$ is a lot noisier (not shown), but the differences can already be seen in Fig. 11a,b for mid-latitudes. Again, it seems that the meteorological analyses used to force the model introduce spurious variations which affect the trend calculation, while diagnosis of trends in the real atmosphere might separate a cleaner "chemical" signal.

Finally, from Fig. 11 we can note that the effect of increased bromine is confined to the lower stratosphere where the bromine cycles are important.

\section{Conclusions}

We have used the SLIMCAT off-line 3-D chemical transport model to investigate long-term changes in stratospheric ozone in the mid-latitude lower and upper stratosphere. The CTM was forced using ECMWF ERA-40 reanalyses from 1977 until the end of 2001 and then operational analyses until the end of 2004. The configuration of the model $(\sigma-\theta$ levels with vertical motion above $350 \mathrm{~K}$ from diagnosed heating rates) was chosen to give the most realistic Brewer-Dobson circulation with these analyses.

A key message from these simulations is that care is needed when using analysed meteorological data, or results which depend on such data, for long-term trend studies. Models which are forced by reanalyses certainly capture much of the apparent interannual variability (e.g. in column ozone) but the analyses also exhibit spurious features. For the

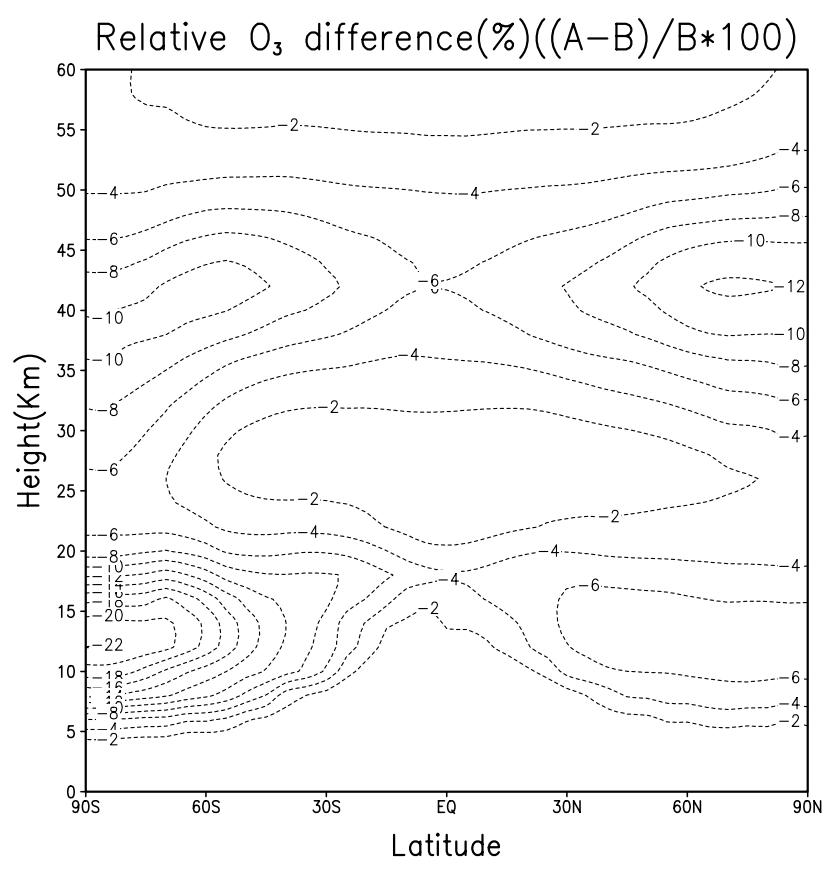

Fig. 12. Latitude-height plot of the percentage difference in zonal mean annual mean ozone between run A and run B for 2004.

ERA-40 data used here these include producing very large NH CTM ozone columns in the late 1980s and upper stratospheric temperature decreases around 1985 which lead to local ozone increases. Nevertheless, the analyses do provide realistic meteorology (e.g. more realistic polar temperatures than would be calculated by a GCM) against which chemical experiments can be performed.

A number of CTM experiments have been performed to assess the impact of increasing halogens and bromine from very short-lived (VSL) species on mid-latitude ozone. The basic model reproduces the observed anomalies of column ozone in the NH, with the exception of the late 1980s, where the model has too large values, and an overestimate of the dip around 1992. The model generally performs less well for the SH column ozone anomaly relative to 1980 values. The model overestimates the decrease through 2002, although this could be explained by an overestimation of the 1980 values, and also produces a marked decrease around 1993 which is not observed. This feature is seen in essentially all 2-D and 3 -D model runs and its absence in the observations has not been explained (see WMO, 2003). For bromine from VSL species, our simulations agree with the 2-D results of Salawitch et al. (2005) on the importance of this extra $\mathrm{Br}_{\mathrm{y}}$ primarily during times of elevated aerosol loading. This is despite the Salawitch et al. (2005) study not explicitly treating VSL species but simply adding 4-8 pptv of bromine throughout the stratosphere.

Trends in the model runs have been analysed using a regression model and by fitting the chemical signal to an EESC 
function. The modelled trend profile captures the observed double peak structure with large losses in the lower stratosphere and the upper stratosphere, although the model appears to overestimate the trends in the very low stratosphere near $10 \mathrm{~km}$. However, the trends from the basic model do not show such a clean structure as the observations. Modelmodel differences which isolate the effect of increasing halogens show a "fingerprint" which matches the observations much better, especially for the variation with latitude and height. We would argue that the trend calculation is somewhat compromised by unrealistic variations in the analyses used to force the model.

Finally, the model has been used to investigate the variation of $\mathrm{O}_{3}$ at $40 \mathrm{~km}$. In this region the model $\mathrm{O}_{3}$ is affected by variations in temperature and transport of $\mathrm{CH}_{4}$. Together these produce variations which can be larger than those due to changes in $\mathrm{Cl}_{\mathrm{y}}$ loading. Although the modelled variations in temperature and long-lived tracers may not be realistic, this demonstrates the difficulty in separating such effects from ozone observations in the real atmosphere. This emphasises that the diagnosis of the onset of recovery from halogen-catalysed loss at $40 \mathrm{~km}$, similar to that which has been performed in the Antarctic LS (Yang et al., 2005), needs careful separation of these effects.

Acknowledgements. This work was supported by the UK Natural Environment Research Council and by the EU through the SCOUT$\mathrm{O} 3$ project. We thank V. Fioletov for help with the trend analysis and W. Randel for help with the HALOE data. We thank BADC for helping to provide the ECMWF analyses.

Edited by: M. Dameris

\section{References}

Chipperfield, M. P.: Multiannual simulations with a threedimensional chemical transport model, J. Geophys. Res., 104, 1781-1805, 1999.

Chipperfield, M. P.: A three-dimensional model study of longterm mid-high latitude lower stratosphere ozone changes, Atmos. Chem. Phys., 3, 1253-1265, 2003.

Chipperfield, M. P.: New Version of the TOMCAT/SLIMCAT OffLine Chemical Transport Model: Intercomparison of Stratospheric Tracer Experiments, Q. J. R. Meteorol. Soc., 132, 11791203, doi:10.1256/qj.05.51, 2006.

Chipperfield, M. P. and Jones, R. L.: Relative influences of atmospheric chemistry and transport on Arctic $\mathrm{O}_{3}$ trends, Nature, 400, 551-554, 1999.

Chipperfield, M. P., Feng, W., and Rex, M.: Arctic Ozone Loss and Climate Sensitivity: Updated ThreeDimensional Model Study, Geophys. Res. Lett., 32(11), L11813, doi:10.1029/2005GL022674, 2005.

Dorf, M.: PhD thesis, University of Heidelberg, Heidelberg, Germany, 2005.

Dorf, M., H. Bösch, A. Butz, C. Camy-Peyret, M. P. Chipperfield, A. Engel, F. Goutail, K. Grunow, F. Hendrick, S. Hrechanyy, B. Naujokat, J.-P. Pommereau, M. Van Roozendael,
C. Sioris, F. Stroh, F. Weidner, and K. Pfeilsticker: Balloonborne stratospheric BrO measurements: Comparison with Envisat/SCIAMACHY BrO limb profiles, Atmos. Chem. Phys., 6, 2483-2501, 2006.

Feng, W., Chipperfield, M. P., Davies, S., Sen, B., Toon, G., Blavier, J. F., Webster, C. R., Volk, C. M., Ulanovsky, A., Ravegnani, F., von der Gathen, P., Jost, H., Richard, E. C., and Claude, H.: Three-dimensional model study of the Arctic ozone loss in 2002/2003 and comparison with 1999/2000 and 2003/4, Atmos. Chem. Phys., 5, 139-152, 2005.

Hadjinicolaou, P., Jrrar, A., Pyle, J. A., and Bishop, L.: The dynamically driven long-term trend in stratospheric ozone over northern mid-latitudes, Q. J. Roy. Met. Soc., 128, 1393-1412, 2002.

Hadjinicolaou, P., Pyle, J. A., and Harris, N. R. P.: The recent turnaround in stratospheric ozone over northern middle latitudes: A dynamical modelling perspective, Geophys. Res. Lett., 32, L12821, doi:10.1029/2005GL022476, 2005.

Montzka, S., Butler, J., Hall, B., Mondell, D., and Elkins, J.: A decline in tropospheric organic bromine, Geophys. Res. Lett., 30, 1826-1829, 2003.

Newman, P. A., Gleason, J. F., McPeters, R. D., and Stolarksi, R. S.: Anomalously low ozone over the Arctic, Geophys. Res. Lett., 24, 2689-2692, 1997.

Pfeilsticker, K., Sturges, W. T., Bösch, H., Camy-Peyret, C., Chipperfield, M. P., Engel, A., Fitzenberger, R., Müller, M., Payan, S., and Sinnhuber, B.-M.: Lower stratospheric organic and inorganic bromine budget for the Arctic winter 1998/99, Geophys. Res. Lett., 27, 3305-3308, 2000.

Salawitch, R. J., Weisenstein, D. K., Kovalenko, L. J., Sioris, C. E., Wennberg, P. O., Chance, K., Ko, M. K. W., and McLinden, C. A.: Sensitivity of ozone to bromine in the lower stratosphere, Geophys. Res. Lett., 32, L05811, doi:10.1029/2004GL021504, 2005.

Sinnhuber, B. M., Arlander, D. W., Bovensmann, H., Burrows, J. P., Chipperfield, M. P., Enell, C. F., Friess, U., Hendrick, F., Johnston, P. V., Jones, R. L., Kreher, K., Mohamed-Tahrin, N., Muller, R., Pfeilsticker, K., Platt, U., Pommereau, J. P., Pundt, I., Richter, A., South, A. M., Tornkvist, K. K., Van Roozendael, M., Wagner, T., and Wittrock, F.: Comparison of measurements and model calculations of stratospheric bromine monoxide J. Geophys. Res., 107(D19), 4398, doi:10.1029/2001JD000940, 2002.

Stolarski, R. S., Douglass, A. R., Steenrod, S., and Pawson, S.: Trends in stratospheric ozone: Lessons learned from a 3D chemical transport model, J. Atmos. Sci., 63(3) 1028-1041, 2006.

Uppala, S. M., Kallberg, P. W., Simmons, A. J., Andrae, U., Bechtold, V. D., Fiorino, M., Gibson, J. K., Haseler, J., Hernandez, A., Kelly, G. A., Li, X., Onogi, K., Saarinen, S., Sokka, N., Allan, R. P., Andersson, E., Arpe, K., Balmaseda, M. A., Beljaars, A. C. M., Van De Berg, L., Bidlot, J., Bormann, N., Caires, S., Chevallier, F., Dethof, A., Dragosavac, M., Fisher, M., Fuentes, M., Hagemann, S., Holm, E., Hoskins, B. J., Isaksen, L., Janssen, P. A. E. M., Jenne, R., McNally, A. P., Mahfouf, J. F., Morcrette, J. J., Rayner, N. A., Saunders, R. W., Simon, P., Sterl, A., Trenberth, K. E., Untch, A., Vasiljevic, D., Viterbo, P., and Woollen, J.: The ERA-40 re-analysis, Q. J. Roy. Meteorol. Soc., 131(612), 2961-3012 (Part B), 2005,

van Noije, T. P. C., Eskes, H. J., van Weele, M., and van Velthoven, P. F. J.: Implications of the enhanced Brewer-Dobson circulation in European Centre for Medium-Range Weather Forecasts 
reanalysis ERA-40 for the stratosphere-troposphere exchange of ozone in global chemistry transport models, J. Geophys. Res.Atmos., 109(D19), D19308, 2004.

World Meteorological Organization (WMO): Scientific Understanding of Ozone Depletion: 2002, Global Ozone Research and Monitoring Project - Report No. 47, World Meteorological Organization, Geneva, 2003.
Yang, E. S., Cunnold, D. M., Newchurch, M. J., and Salawitch, R. J.: Change in ozone trends at southern high latitudes, Geophys. Res. Lett., 32, L12812, doi:10.1029/2004GL022296, 2005.

Ziemke, J. R., Chandra, S., McPeters, R. D., and Newman, P. A.: Dynamical proxies of column ozone with applications to global trend models, J. Geophys. Res., 102, 6117-6129, 1997. 